MTPH Journal, Volume 4, No. 2, September 2020

\title{
HUBUNGAN PERILAKU MEROKOK DENGAN TEKANAN DARAH SISTOLIK DAN TEKANA DARAH DIASTOLIK PADA AWAK KAPAL DI WILAYAH KERJA KANTOR KESEHATAN PELABUHAN PALANGKARAYA
}

\author{
Novvy Anggraenny, Santi Martini \\ Departemen Epidemiologi, Fakultas Kesehatan Masyarakat, Universitas Airlangga \\ Email:nov_vy@yahoo.com
}

\begin{abstract}
Hypertension can be caused by smoking behaviour. The consumption of cigarette in Indonesia was the third-largest in the world and which about 225,700 were death in 2015 because of the diseases tobacco causes This study is aimed at analysing the association between smoking behaviour and systolic blood pressure and diastolic blood pressure on the ship crews in the Porth Health Office of Palangkaraya working area. This study used observational analytic using a cross-sectional research design. The whole of the ship crew population was selected on November 2018 in the working area of the major office of Porth Health Office Palangkaraya. Data analysis used the calculation of Prevalence Ratio value. This study has revealed that $77.8 \%$ of subjects had smoking behaviour, subjects had systolic blood pressure $\geq 140 \mathrm{mmHg}$ were $20,3 \%$ and subjects had diastolic blood pressure $\geq 90 \mathrm{mmHg}$ were $14,8 \%$. The $P R$ value of smoking behaviour was 2,8, several cigarettes are $\geq 11$ stick/day was 2,0; several cigarettes were 1-10 stick/day was 4,0; the value reveals that there was an association between smoking behaviour and systolic blood pressure. The PR value of smoking behaviour was 2,0; several cigarettes were $\geq 11$ stick/day was 1,5; several cigarettes were 1-10 stick/day was 2,6; the value reveals that there was an association between smoking behaviour and systolic blood pressure. From this study, it can be concluded that there was an association between smoking and systolic blood pressure and diastolic blood pressure.
\end{abstract}

Keywords: Systolic Blood Pressure, Diastolic Blood Pressure Smoking Behavior, Crew'S Ship

\begin{abstract}
ABSTRAK
Hipertensi dapat disebabakan oleh perilaku merokok. Jumlah konsumsi rokok di Indonesia merupakan yang terbanyak ketiga di seluruh dunia dan sekitar 225.700 orang yang telah meninggal diakibatkan penyakit karena konsumsi tembakau di tahun 2015. Penelitian ini bertujuan untuk menganalisis hubungan antara perilaku merokok dan tekanan darah sistolik dan tekanan darah diastolik pada awak kapal diwilayah kerja Kantor Kesehatan Pelabuhan Palangkaraya bulan November 2018. Penelitian ini adalah penelitian jenis observasional analitik yang menggunakan desain penelitian cross sectional. Penelitian ini menggunaka semua populasi awak kapal pada bulan November 2018 di kantor induk wilayah kerja Kantor Kesehatan Pelabuhan Palangkaraya. Analisis data yang digunakan dalam penelitian ini yaitu dengan menghitung nilai Prevalance Ratio. Hasil penelitian ini menyebutkan sebesar $77,80 \%$ subyek memiliki perilaku merokok, subyek yang mempunyai tekanan darah sistolik $\geq 140 \mathrm{mmHg}$ adalah $20,3 \%$ dan subyek memiliki tekanan darah distolik $\geq 90 \mathrm{mmHg}$ adalah $14,8 \%$. Hasil PR untuk perilaku merokok adalah 2,8; jumlah rokok yang dikonsumsi $\geq 11$ batang/hari adalah 2,0; jumlah rokok $1-10$ batang/hari adalah 4,0; hasil tersebut
\end{abstract}


menyatakan ada hubungan antara perilaku merokok dengan tekanan darah sistolik. Hasil PR untuk perilaku merokok adalah 2,0 , jumlah rokok yang dikonsumsi $\geq 11$ batang/hari adalah 1,5 ; jumlah rokok 1-10 batang/hari adalah 2,6; hasil tersebut menyatakan ada hubungan antara perilaku merokok dengan tekanan darah distolik. Kesimpulan dari penelitian ini adalah perilaku merokok berhubungan dengan nilai tekanan darah sistolik dan tekanan darah distolik, perilku merokok berpotensi menigkatnya risiko memiliki tekanan darah sistolik $\geq 140 \mathrm{mmHg}$ dan tekanan darah diastolik $\geq 90$ $\mathrm{mmHg}$.

Kata kunci: Perilaku Merokok, Tekanan darah sistolik, Tekanan darah diastolic, Awak kapal

\section{PENDAHULUAN}

Penyebab utama kematian orang-orang yang berumur kurang dari 70 tahun secara global adalah diakibatkan oleh penyakit tidak menular. Perubahan pada tubuh yang memicu timbulnya penyakit disebaknan diataranya oleh gaya hidup yang semakin modern yang dapat memudahkan dan memeberi, kenyamanan, aktivitas fisik yang kurangdan bermacam-macam produk makanan ${ }^{1}$.

Kematian karena penyakit tidak menular pada individu yang berumur $<70$ tahun di dunia, sebanyak $46 \%$ dikarenakan oleh penyakit jantung dan pembuluh darah. Penyakit jantung kororner (PJK) terjadi sebanyak $43 \%$ dari keseluruhan penyakit jantung dan pembuluh darah dan ditemukan sebanyak 7,40 juta kematian akibat PJK di seluruh dunia ${ }^{2}$.

Faktor risiko utama terjadinya penyakit jantung koroner salah satunya adalah karena terjadinya peningkatan tekanan darah. Tekanan darah tinggi mengakibatkan sebanyak $50 \%$ kematian pada penyakit kardiovaskular dan karena penyebab yang lain yaitu karena perilaku konsumsi rokok tembakau baik aktif maupun perokok yang pasif yaitu sebanyak $30 \%{ }^{2}$.
Hipertensi adalah sebuah keadaan dimana pada saat tekanan darah pada pembuluh darah mengalami kanaikan untuk rentang waktu yang lama dan secara berkelanjutan. Hipertensi juga merupakan faktor risiko terjadinya penyakit pembuluh darah yang lain yang juga sangat berbahaya yaitu dapat terjadi serangan penyakit stroke ${ }^{3}$.

Berdasarkan dari sejumlah penelitian yang dilakukan menyatakan bahwa faktor risiko penakit hipertensi diantaranya adalah umur, jenis kelamin,obesitas, merokok, riwayat keluarga hipertensi dan pola makan ${ }^{4}$. Masalah yang sering ditemui adalah faktor risiko merokok, penelitian yang telah dilakukan dilakukaan di kota Padang menyatakan bahwa ada hubungan antara perilaku merokok dengan kejadian hipertensi dan faktor yang mempengaruhi lainnya adalah lamanya subyek merokok menunjukan terdapat hubungan dengan kejadian hipertensi dan juga faktor jenis rokok juga memengaruhi tekanan darah ${ }^{6}$.

Masalah yang dihadapi oleh seluruh negara yang sangat berbahaya bagi kesehatan 
salah satunya adalah perilaku merokok, di didapatkan sekitar 942.000.000 orang pria dan 175.000.000 wanita yang berumur 15 tahun keatas telah mengkonsumsi rokok di tahun 2015. China, India dan Indonesia merupakan tiga negara dengan urutan konsumsi rokok paling besar di dunia. Lebih dari 225.700 orang di Indonesia merupakan korban yang meninggal diakibatkan penyakit karena tembakau. Jumlah konsumsi tembakau yang dilakukan oleh anakanak yang berumur 10-14 tahun adalah sebanyak 469 ribu orang di tahun 2015 dan untuk orang umur 15 tahun ke atas adalah sebanayak 53.248.000 orang ${ }^{7}$.

Salah satu kelompok pekerja dengan karakteristiknya hampir sebagian besar adalah laki-laki dan bekerja di lapangan adalah awak kapal. Kantor Kesehatan Pelabuhan Palangkaraya mendapatkan hasil dari kegiatan surveilans dalam waktu bulan Januari sampai dengan Maret 2018 didapatkan 41,6 \% awak kapal yang diperiksa mempunyai tekanan darah sistole $\geq 140 \mathrm{mmHg}$ dan atau diastole $\geq 90$ mmHg. Penelitian yang dilakukan ini memiliki tujuan yaitu untuk menganalisis hubungan antara perilaku merokok dan tekanan darah sistolik dan tekanan darah diastolik pada awak kapal diwilayah kerja Kantor Kesehatan Pelabuhan Palangkaraya ${ }^{8}$.

\section{METODE PENELITIAN}

Penelitian yang digunakan adalah jenis penelitian observasional analitik dengan mengunakan. rancang bangun penelitian cros sectional. Penelitian dilakukan pada bulan November 2018 di wilayah kerja kantor induk Kantor Kesehatan Pelabuhan Palangkaraya dengan menggunakan total populasi awak kapal dalam bulan November 2018 yang telah sesuai dengan kriteria inkusi. Variabel yang menjadi topik penelitian ini adalah perilaku merokok, jumlah rokok yang dikonsumsi, tekanan darah sistole dan tekanan darah diastole. Instrumen penelitian yang dipakai dalam penelitian ini adalah kuesioner dan data isian hasil pengukuran tekanan darah sistolik dan tekanan darah diastolik. Kriteria diagnosis JNC VII 2003 digunakan untuk penetapan kasus hipertensi adalah nilai hasil pemerikasaan tekanan darah sistole $\geq 140 \mathrm{mmHg}$ dan atau tekanan darah diastole $\geq 90 \mathrm{mmHg}$.

Proses manajemen data yang dilakukan dalam penelitian ini dilakukan dengan dua fase yaitu pengumpulan data pada fase pertama dan pengolahan data di fase kedua. Proses pengumpulan data yang dilakukan dalam penelitian ini dengan cara datang menemui awak kapal di kapal yang sedang sandar dipelabuhan. Data yang digunakan dalam penelitian ini merupakan data primer yang merupakan data yang didapatkan langsung oleh peneliti dari subyek. Data diperoleh dari hasil pengisian kuesioner dan pemeriksaan tekanan darah pada awak kapal. Analisa data yang dilakukan dalam penelitian ini adalah dengan perhitungan nilai Prevalance Ratio. 
Kriteri inklusi untuk subyek penelitian adalah: semua awak buah kapal yang berada di kapal yang diperiksa dan yang tidak keberatan untuk menjadi subyek penelitian, awak kapal yang mengerjakan aktifitas fisik di pekerjaannya (paling sedikit 10 menit dalam suatu pekerjaan dengan tidak berhenti dan secara kuseluruhan berjumlah 150 menit selama lima hari dalam satu minggu).

Kriteria ekslusi untuk subyek penelitian adalah: swak kapal yang sebelumya telah didiagnosa menderita hipertensi, awak kapal yang berdasarakan pengukuran BMI menderita obesitas, awak kapal yang telah menderita penyakit gagal ginjal kronik, awak kapal yang telah memiliki perilaku konsumsi alkohol, (sudah konsumsi alkohol 10 tahun sampai waktu penelitian), awak kapal yang mengkonsumsi makanan dari luar yang tidak disediakan di kapal, awak kapal yang mempunyai penyakit Diabetes melitus sebelumnya.

\section{HASIL DAN PEMBAHASAN}

Hasil dalam penelitian ini didapatkan bahwa jumlah awak kapal pada bulan November di wilayah kerja kantor induk Kantor Kesehatan Pelabuhan Pangkaraya adalah sebanyak 74 orang dan sebanayak 54 orang yang telah sesuai dengan kriteria sebagai subyek dalam penelitian ini. Semua awak kapal yang menjadi subyek penelitian ini adalah berjenis kelamain kelamin laki-laki. Subyek penelitian ini umurnya sangat beragam yaitu dari yang uisa termuda yaitu 18 tahun sedangkan umur yang tertua yaitu 62 tahun. Sebesar 66,67\% kelompok umur yang terbanyak adalah umur subyek pada kelompok 18 - 35 tahun adalah sebesar 66,67\%. Distribusi Subyek Penelitian Berdasar Riwayat Hipertensi di Keluarga, Umur, Perilaku Merokok dan Lama Merokok, Serta Tekanan Darah Sistolik dan Tekanan Darah Diastolik

Sebesar 94,4\% dari seluruh subjek penelitian besar subyek tidak memiliki riwayat hipertensi dalam keluarga. Subjek penelitian yang memiliki perilaku merokok adalah sebesar $77,7 \%$. Sebesar $44,5 \%$ subyek penelitian ditemukan mengkonsumsi rokok >11 batang/hari.

Tabel 1. Distibusi Subyek Penelitian Berdasarkan Riwayat Hipertensi di Keluarga, Umur, Status perilaku merokok dan Lama Merokok, Serta Tekanan Darah Sistolik dan Tekanan Darah Diastolik di Wilayah Kerja Kantor Kesehatan Pelabuhan Palangkaraya

\begin{tabular}{lcr}
\hline Ciri-ciri Subyek & Jumlah & Persentase \\
\hline Riwayat Hipertensi di Keluarga & \\
Ya & 3 & 5,5 \\
Tidak & 51 & 94,4 \\
\hline Umur subyek (tahun) & & \\
18-35 & 36 & 66,6 \\
36-62 & 19 & 33,6 \\
\hline Riwayat Hipertensi di Keluarga & \\
Ya & 3 & 5,5 \\
Tidak & 51 & 94,4 \\
\hline Status Merokok & & \\
Ya & 42 & 77,7 \\
Tidak & 12 & 22,2 \\
\hline Jumlah rokok yang dikonsumsi \\
$\quad \geq 11$ batang/hari & 24 & 44,5 \\
\hline
\end{tabular}




\begin{tabular}{ccr}
\hline Ciri-ciri Subyek & Jumlah & Persentase \\
\hline 1 -10 batang/hari & 18 & 33,3 \\
Tidak merokok & 12 & 22,2 \\
\hline Hasil Tekanan Darah Sistole & \\
$\geq 140 \mathrm{mmHg}$ & 11 & 20,3 \\
$<140 \mathrm{mmHg}$ & 43 & 79,6 \\
\hline Hasil Tekanan Darah Diastole & \\
$\geq 90 \mathrm{mmHg}$ & 8 & 14,8 \\
$<90 \mathrm{mmHg}$ & 46 & 85,1 \\
\hline Total & 54 & 100,0 \\
\hline
\end{tabular}

Sebesar 20,3\% subyek penelitian ditemukan memiliki tekanan darah sistole $\geq 140$ $\mathrm{mmHg}$ dan sebesar $14,8 \%$ subyek memiliki tekanan darah diastolik $\geq 90 \mathrm{mmHg}$.

Tabel 2. Distribusi Subyek Penelitian Berdasarkan Perilaku Merokok dan Jumlah Batang Rokok yang Dikonusmsi dengan Tekanan Darah Sistolik di Wilayah Kerja Kantor Kesehatan Pelabuhan Palangkaraya

\begin{tabular}{|c|c|c|c|c|}
\hline \multirow{3}{*}{ Perilaku Subyek } & \multicolumn{4}{|c|}{ Tekanan Darah Sistole } \\
\hline & \multicolumn{2}{|c|}{ TDS $\geq 140$} & \multicolumn{2}{|c|}{ TDS $<140$} \\
\hline & $\mathrm{n}$ & $\%$ & $\mathrm{n}$ & $\%$ \\
\hline \multicolumn{5}{|l|}{ Perilaku Merokok } \\
\hline Merokok & 10 & 90,9 & 32 & 74,4 \\
\hline $\begin{array}{l}\text { Tidak } \\
\text { merokok }\end{array}$ & 1 & 9,0 & 11 & 25,5 \\
\hline \multicolumn{5}{|c|}{ Jumlah rokok yang dikonsumsi (batang/hari) } \\
\hline$\geq 11$ & 4 & 36,4 & 20 & 46,5 \\
\hline $1-10$ & 6 & 54,5 & 12 & 27,9 \\
\hline $\begin{array}{l}\text { Tidak } \\
\text { merokok }\end{array}$ & 1 & 9,1 & 11 & 25,6 \\
\hline Total & 11 & 100,0 & 43 & 100,0 \\
\hline
\end{tabular}

Subyek penelitian yang memiliki tekanan darah sistole (TDS) $\geq 140 \mathrm{mmHg}$ adalah subyek penelitian yang merokok yaitu sebesar 90,9 \% dan sebagaian besar subyek mengkonsumsi rokok sebanyak 1-10 batang/hari yaitu sebesar $54,5 \%$.
Tabel 3. Distribusi Subyek peneliitan Berdasarkan Status dan Lama Merokok dengan Tekanan Darah Diastole di Wilayah Kerja Kantor Kesehatan Pelabuhan Palangkaraya.

\begin{tabular}{lcccc}
\hline \multirow{2}{*}{ Kategori } & \multicolumn{4}{c}{ Tekanan Darah Diastole } \\
\cline { 2 - 5 } & \multicolumn{2}{c}{ TDD $\geq 90$} & \multicolumn{2}{c}{ TDD $<90$} \\
\cline { 2 - 5 } & $\mathrm{n}$ & $\%$ & $\mathrm{n}$ & $\%$ \\
\hline Perilaku Merokok & & & \\
Merokok & 7 & 87,5 & 35 & 76,1 \\
Tidak & 1 & 12,5 & 11 & 23,9 \\
merokok & & & & \\
\hline Jumlah rokok yang dikonsumsi(batang/hari) \\
$\geq 11$ & 3 & 37,5 & 21 & 47,5 \\
$1-10$ & 4 & 50,0 & 14 & 30,4 \\
Tidak & 1 & 12,5 & 11 & 23,9 \\
merokok & & & 46 & 100,0 \\
\hline Total & 8 & 100,0 & 46 \\
\hline
\end{tabular}

Sebagian besar subyek dengan tekanan darah diastolik TDD $\geq 90 \mathrm{mmHg}$ adalah memiliki perilaku merokok sebesar $87,5 \%$ dan yang mengkonsumsi rokok sebanyak 1-10 batang/hair sebesar $50 \%$.

Subyek penelitian dengan hasil tekanan darah sistolik $\geq 140 \mathrm{mmHg}$ merupakan subyek yang memiliki perilaku merokok yaitu 90,9\%. Subyek yang merokok dengan TDS $\geq 140$ mmHg didapatkan nilai Prevalence Ratio (PR) adalah sebesar 2,8 artinya subyek yang memiliki perilaku merokok memiliki risiko terhadap TDS $\geq 140 \mathrm{mmHg} 2,8$ kali lebih tinggi bila diperbandingkan pada subyek yang tidak mempunyai perilaku merokok.

Sebesar $87,5 \%$ subyek penelitian yang mempunyai $\mathrm{TDD} \geq 90 \mathrm{mmHg}$ merupakan subyek yang memiliki kebiasaan merokok. Subyek yang memiliki kebiasaan merokok 
dengan tekanan darah diastolik $\geq 90 \mathrm{mmHg}$ memiliki nilai $P R=2,0$ berarti subyek yang meiliki kebiasaan merokok memiliki risiko terhadap tekanan darah diastolik $\geq 90 \mathrm{mmHg}$ yaitu sebesar 2 kali lebih besar jika diperbandingkan pada subyek yang tidak mempunyai perilaku merokok.

Hasil dari seluruh subyek penelitian didapatkan subyek yang nilai TDS $\geq 140 \mathrm{mmHg}$ yang paling besar yaitu subyek yang mengkonsumsi rokok sebanyak 1-10 batang/hari adalah sebesar 54,5\%. Hasil prevalence ratio bagi subyek mengkonsumsi rokok sebanyak $\geq 11$ batang/hari tahun adalah 2,0 yang berarti subyek yang mengkonsumsi rokok sebanyak $\geq 11$ batang/hari memiliki risiko terhadap tekanan darah sistolik $\geq 140 \mathrm{mmHg} 2$ kali lebih besar bila dibandingkan dengan subyek yang tidak merokok. Subyek yang mengkonsumsi rokok sebanyak 1-10 batang/hari mendapat nilai $\mathrm{PR}=$ 4,0 yang berarti subyek yang mengkonsumsi rokok sebanyak 1-10 tbatang/hari memiliki risiko terhadap tekanan darah sistolik $\geq 140$ mmHg 4 kali lebih besar bila dibandingkan dengan subyek yang tidak merokok.

Subyek yang nilai TDD $\geq 90 \mathrm{mmHg}$ sebagian besar adalah subyek yang mengkonsumsi rokok sebanyak 1-10 batang/hari adalah sebesar $50 \%$. Subyek yang mengkonsumsi rokok sebanyak $\geq 11$ batang/hair mendapatkan nilai PR yaitu 1,5 artinya subyek yang mengkonsumsi rokok sebanyak $\geq 11$ batang/hari memiliki risiko terhadap tekanan darah diastolik $\geq 90 \mathrm{mmHg}$ 1,5 kali lebih besar bila dibandingkan dengan subyek yang tidak merokok. Subyek yang mengkonsumsi rokok sebanyak 1-10 batang/hari mendapatkan hasil PR sebesar 2,6 artinya subyek mengkonsumsi rokok sebanyak 1-10 batang/hari memiliki risiko terhadap tekanan darah diastolik $\geq 90 \mathrm{mmHg} 2,6$ kali lebih besar bila dibandingkan dengan subyek yang tidak merokok.

\section{Pembahasan}

\section{Distribusi Subyek penelitian Berdasar Umur,} Riwayat Hipertensi Keluarga, Kebiasan

\section{Merokok, Serta Tekanan Darah}

Penelitian ini semua subyek penelitiannya adalah laki-laki dan diperoleh hasil bahwa sebanyak $77,78 \%$ subyek penelitian memiliki perilaku merokok. Hasil tersebut hampir sama dengan penelitian yang dilakukan di Kabupaten Cianjur Jawa Barat dengan subyek penelitian laki-laki umur dewasa yang menyatakan bahwa sebesar $83,90 \%$ subyek penelitian mempunyai kebiasan merokok ${ }^{9}$.

Penelitian yang telah dilakukan di tempat yang lain juga menyatakan bahwa sebagian besar subyek penelitian yang memiliki perilaku merokok adalah laki-laki yaitu sebesar $89,50 \%{ }^{10}$. Hasil dari penelitian berbeda yang dilakukan di Puskesmas Kolongan Kecamatan Kalawat, Minahasa Utara menyatakan bahwa jumlah subyek penelitian yang memiliki perilaku merokok lebih sedikit yaitu sebanyak $28,10 \%{ }^{11}$. 
Subyek penelitian yang mempunyai tekanan darah sistole $\geq 140 \mathrm{mmHg}$ yaitu sebanyak 20,3\% serta yang mempunyai tekanan darah diastole sebanyak $14,81 \%$. Penelitian juga dilakukan di Republik Czech menyatakan hasil yang serupa yang mana didapatkan bahwa sebanyak $22 \%$ dari seluruh peserta penelitian memiliki riwayat hipertensi ${ }^{12}$. Penelitian serupa yang dilakukan pada lansia di Sawangan Baru memperoleh hasil dalam penelitiannya bahwa sebanyak $26,4 \%$ peserta peneiltian mengalami hipertensi ${ }^{13}$.

Subyek penelitian yang anggota keluarganya mempunyai riwayat menderita hipertensi pada penelitian ini adalah sanyak $5,5 \%$. Persentase yang lebih tinggi diperoleh dalam penelitian yang dilakukan pada sejumlah mahasiswa yang mana jumlah subyek penelitian yang mempunyai anggota keluarga dengan riwayat hipertensi sebesar $25 \%{ }^{14}$.

Penelitian serupa yang dilakukan di Puskesmas Kelayan Timur, Banjarmasin menemukan bahwa jumlah subyek penelitian yang memiliki keluarga dengan riwayat hipertensi yang lebih tinggi yaitu sebesar $46,23 \%{ }^{4}$. Penelitian yang dilakukan di wilayah Puskesmas Kuta Utara memperoleh hasil yang semakin tinggi yaitu jumlah peserta penelitian yang mempunyai riwayat dalam keluarga yang menderita penyakit hipertensi adalah sebesar $66,2 \%{ }^{15}$.

\section{Hubungan Antara Status Merokok dengan} Tekanan Darah Sistol dan Diastol

Penelitian ini mendapatkan hasil bahwa terdapat hubungan antara perilaku merokok dengan tekanan darah sistol dan diastol yaitu subyek penelitian yang merokok memiliki risiko mengalami tekanan darah sistol $\geq 140 \mathrm{mmHg} 2,8$ kali lebih besar daripada orang yang tidak merokok serta subyek penelitian yang merokok memiliki risiko mengalami tekanan darah diastol $\geq 90 \mathrm{mmHg} 2$ kali lebih besar daripada orang yang tidak merokok. Penelitian yang dilakukan di wilker Puskesmas Peukan Bada, Kabupaten Aceh Besar memperoleh hasil yang serupa dengan penelitian ini menyebutkan bahwa perilaku merokok berhubungan dengan kejadian hipertensi pada pasien hipertensi dengan hasil uji statistik nilai $\mathrm{p}=0,01^{16}$.

Penelitian lain yang sejalan yang dilaksankan di Puskesmas Pembina Palembang terhadap pasien dengan hipertensi menyatakan bahwa terdapat hubungan antara perilaku merokok dengan hipertensi dengan hasil uji statistik nilai $\mathrm{p}=0,01^{17}$. Para peneliti yang lain juga menemukan bahwa orang dengan perilaku merokok mempunyai risiko 2,61 kali lebih besar untuk mengalami hipertensi daripada orang yang tidak memiliki perilaku merokok pada TNI di Rumah Sakit Angkatan Laut Dr. Ramelan di Surabaya $^{18}$. Penelitian di negara Italy menemukan bahwa orang yang memiliki perilaku merokok mempunyai tekanan darah 
sistol sentral lebih tinggi dibandingkan orang yang tidak memiliki perilaku merokok ${ }^{19}$.

Penelitian serupa juga dilakukan di negara Pakistan mendapatkan hasil bahwa perilaku merokok memberikan efek yang buruk terhadap kondisi tekanan darah yaitu menyebabkan terjadinya peningkatan tekanan darah pada orang yang memiliki perilaku merokok ${ }^{20}$. Penelitian yang dilakukan di daerah Kabupaten Cianjur, Provinsi Jawa Barat terhadap laki-laki umur dewasa memperoleh hasil bahwa terdapat hubungan yang signifikan antara perilaku merokok dengan kejadian hipertensi di daerah tersebut dengan nilai $\mathrm{p}=0,03^{9}$.

Hasil yang berbeda didapatkan pada penelitian lain yang menyatakan bahwa perilaku merokok bukan merupakan faktor risiko terjadinya masalah hipertensi di wilayah kerja Puskesmas Kuta Utara ${ }^{15}$. Penelitian serupa yang dilaksanakan kepada murid SMK N 1 Padang dengan rentang umur 14-18 tahun memperoleh kesimpulan bahwa perilaku merokok subyek tidak berhubungan dengan tekanan darah sistole maupun diastole dengan hasil uji statistik nilai $\mathrm{p}$ $=0,15^{21}$.

Hasil yang serupa juga disebutkan pada penelitian yang lain yaitu disebutkan tekanan darah sistol orang yang merokok terjadi penurunan sebanyak $1,30 \mathrm{mmHg}$ pada orang yang merokok ringan, terjadi penurunan sebanyak 3,80 $\mathrm{mmHg}$ terhadap orang yang merokok sedang, serta mengalami penurunan sebesar 4,60 mmHg pada perokok berat jika dibandingkan dengan subyek penelitian yang bukan perokok ${ }^{22}$. Hasil penelitian yang lain menyatakan hal yang hampir sama bahwa tidak ditemukan hubungan yang signifikan antara orang yang merokok dan tekanan darah yang didapatkan dari pasien yang berkunjung di poli Jantung Rumah Sakit Haji di Surabaya ${ }^{23}$. Penelitian di Sullia yang pernah dilakukan memperoleh hasil yaitu tekanan darah sistol yang didapatkan dari subyek penelitian yang memiliki perilaku merokok terjadi penurunan yang signifikan daripada subyek penelitian yang tidak memiliki perilaku merokok ${ }^{24}$.

Penelitian yang dilakukan di negara China juga menyebutkan bahwa didapatkan hasil tekanan darah yang lebih rendah pada subyek penelitian dengan yang memiliki perilaku merokok daripada orang yang tidak memiliki perilaku merokok ${ }^{25}$. Hal serupa di negara China sebuah penelitian pada laki-laki umur dewasa menunjukkan hasil tidak terdapat hubungan yang signifikan antara perilaku merokok dengan kejadian hipertensi dengan diperoleh hasil uji statistik dengan nilai $\mathrm{p}=0,85 .{ }^{26}$

Merokok berpotensi menjadikan zat-zat yang bersifat iritan yang terkandung rokok mengiritasi secara bebas pada paru dimana hal tersebut dapat mengakibatkan batuk, sesak napas, serta kanker paru. Zat toksik tersebut yang telah terserap masuk ke dalam pembuluh darah juga dapat menyebabkan perubahan dalam system yang ada di dalam tubuh antara lain detak jantung meningkat menjadi semakin cepat, 
pembuluh darah mudah mengalami kejang dan lebih cepat mengalami kontraksi otot yang tibatiba, serta sel-sel darah menjadi lebih mudah mengalami kejadian terjadinya penggumpalan. Proses aterosklerosis diawali oleh adanya luka pada endotel dimana telah kronik yang bisa diakibatkan oleh adanya zat racun yang berasal dari virus dan bakteri, toksin dari asap rokok, zat radikal bebas, serta bahan-bahan lain yang dapat menyebabkan peradanagn pada pembuluh $\operatorname{darah}^{27}$.

Kejadian aterosklerosis adalah salah satu kejadian asal mula terjadinya penyakit hipertensi dimana adanya masalah yang terjadi dalam susunan anatomi pembuluh darah perifer sehingga selanjutnya mengakibatkan pengerasan atau kejang pada pembuluh darah. Pengerasan atau kejang pada pembuluh darah bisa juga terjadi bersama dengan penyempitan pembuluh darah serta adanya kemungkinan penambahan ukuran plak dimana hal tersebut dapat menghambat sirkulasi darah di bagian darah tepi.

Terjadinya pengerasan atau kejang serta sirkulasi darah yang lambat itu mengakibatkan tugas kerja jantung menjadi lebih besar yang selanjutnya akan dilakukan kompensasi oleh jantung yang caranya yaitu melakukan peningkatan kerja jantung dengan memompa semakin cepat sehingga mempengaruhi tekanan darah menjadi meningkat pada sistem aliran darah ${ }^{1}$. Perilaku orang yang merokok diketahui juga dapat menyebabkan peningkatan partum- buhan sel kanker pada pasien yang menderita kanker menjadi lebih cepat dan hal tesebut juga dapat menyebabkan kejadian kematian semakin cepat sekitar 8-10 tahun dibandingkan dengan pasien penderita kanker yang diketahui tidak pernah mengkonsumsi rokok ${ }^{28}$

\section{Hubungan Jumlah rokok dengan Tekanan Darah Sistole dan Diastole}

Hasil dari penelitian yang dilakukan pada awak kapal ini menunujukan hasil yaitu terdapat hubungan antara banyaknya batang rokok yang dikonsumsi per hari dengan tekanan darah sistolik maupun diastolik. Hasil menujukkan bahwa subyek penelitian yang mengkonsumsi rokok sebanyak $\geq 11$ batang/hari mempunyai risiko mengalami tekanan darah sistolik $\geq 140$ $\mathrm{mmHg}$ dengan nilai risiko 2,0 kali lebih berisiko daripada subyek yang tidak merokok. Subyek penelitian yang mengkonsumsi rokok sebanyak 1-10 batang/hari mempunyai risiko mengalami tekanan darah sistolik $\geq 140 \mathrm{mmHg}$ dengan nilai risiko 4,0 kali lebih besar daripada subyek yang tidak merokok.

Subyek penelitian yang mengkonsumsi rokok sebanyak $\geq 11$ batang/hari mempunyai risiko mengalami tekanan darah diastolik $\geq 90$ $\mathrm{mmHg}$ dengan nilai risiko 1,5 kali serta subyek penelitian yang mengkonsumsi rokok sebanyak 1-10 batang/hari mempunyai risiko mengalami tekanan darah diastolik $\geq 90 \mathrm{mmHg}$ dengan nilai risiko 2,6 kali

Penelitian lain yang sejalan dengan penilitian ini adalah penelitian pada karyawan 
pria di perusahaan Nasmoco Semarang menyebutkan bahwa jumlah rokok yang dikonsumsi setiap hari berhubungan dengan hasil pemeriksaan tekanan darah yang menujukan hasil uji statistik $\mathrm{p}=0,000^{29}$.

Hasil penelitian ini berbeda dengan yang dilakukan pada penduduk di palembang yang menyatakan hasil tidak ada hubungan antara jumlah rokok yang dikonsumsi dengan kejadian hipertensi yang menunjukan hasil uji statistik nilai $\mathrm{p}=0,078^{5}$.

\section{SIMPULAN DAN SARAN}

\section{Simpulan}

Hasil dari penelitian ini adalah didapatkan bahwa perilaku merokok berhubungan dengan tekanan darah yaitu perilaku merokok dapat menyebabkan peningkatan tekanan darah sistol maupun diastol.

\section{Saran}

Edukasi mengenai bahaya merokok kepada awak kapal, dimana merokok meningkatkan dapat menigkatkan tekanan darah dan penyakit-penyakit yang timbul akibat peningkatan tekanan darah tersebut seperti penyakit jantung, gagal ginjal, stroke dan lainlain.

\section{REFERENSI}

1. Suiraoka I. Penyakit Degeneratif. Yogyakarta: Nuha Medika; 2012.

2. WHO. Chapter 6 Non communicable diseases.2015. http://www.who.int/gho/publications/mdgssdgs/MDGs-SDGs2015_chapter6.pdf?ua=1.
3. Khairatunnisa, Sari DM. Faktor Risiko yang Berhubungan Dengan Kejadian Stroke Pada Pasien Di RSU H. Sahudin Kutacane Kabupaten Aceh Tenggara. J JUMANTIK. 2017;2(1):60. file:///C:/Users/Acer ES1132-C7SF/Downloads/962-2239-1-PB (1).pdf.

4. Putra AMP, Ulfah A. Analisis Faktor Risiko Hipertensi di Puskesmas Kelayan Timur Kota Banjarmasin. J Ilm Ibnu Sina. 2016;1(2):256-264.

https://doaj.org/article/17c8df59e26e40be9e 42253b6413adb0.

5. Sartik, RM. Suryadi Tjekyan MZ. FaktorFaktor Risiko dan Angka Kejadian Hipertensi Pada Penduduk Palembang. J Ilmu Kesehat Masy. 2017;8(November):180-191. doi:doi.org/10.26553/jikm.2017.8.3.180191

6. Setyanda GOY, Sulastri D, Lestari Y. Hubungan Merokok dengan Kejadian Hipertensi pada Laki- Laki Usia 35-65 Tahun di Kota Padang. J Kesehat Andalas. 2015;4(2):434-440. doi:10.1177/0963662510363054

7. Drope J, Schluger N, Cahn Z, et al. The Tobacco Atlas. Atlanta: American Cancer Society and Vital.; 2018. www.tobaccoatlas.org.

8. KKP Kelas III Palangkaraya. Laporan Surveilans PKSE Tahun 2018. Palangkaraya; 2018.

9. Diana R, Khomsan A, Nurdin NM, Anwar F, Riyadi H. Smoking Habit, Physical Activity and Hypertension Among Middle Aged Men. Media Gizi Indones. 2018;13(1):5761. doi:10.20473/mgi.v13i1.57

10. Faridah F. Analisis faktor faktor penyebab perilaku merokok remaja di SMK " $X$ " Surakarta. J Kesehat Masy. 2015;3(3, April 2015):887-897. http://ejournals1.undip.ac.id/index.php/jkm.

11. Suoth M, Bidjuni H, Malara RT. Hubungan Gaya Hidup Dengan Kejadian Hipertensi Di Puskesmas Kolongan Kecamatan Kalawat 
Kabupaten Minahasa Utara. ejournal keperawatan(e-Kp). 2014;2(1):1-10.

12. Pankova A, Kralikova E, Fraser K, Lajka J, Svacina S, Matoulek M. No difference in hypertension prevalence in smokers, former smokers and non-smokers after adjusting for body mass index and age: A cross-sectional study from the Czech Republic, 2010. Tob Induc Dis. 2015;13(1). doi:10.1186/s12971015-0049-4

13. Mahmudah S, Maryusman T, Arini FA, Malkan I. Hubungan Gaya Hidup Dan Pola Makan Dengan Kejadian Hipertensi Pada Lansia Di Kelurahan Sawangan Baru. Biomedika. 2015;7(2):43-51.

14. Alhawari HH, Al-Shelleh S, Alhawari HH, et al. Blood Pressure and Its Association with Gender, Body Mass Index, Smoking, and Family History among University Students. Int J Hypertens. 2018;2018. doi:10.1155/2018/4186496

15. Widyartha I. J, Putra WGAE, Seri Ani L. Family History, Stress, Less Physical Activity, Obesity and Excessive Salty Food Consumption as Risk Factors of Hypertension. Public Heal Prev Med Arch. 2018;4(2):186.

doi:10.24843/PHPMA.2016.v04.i02.p10

16. Fitria, Amin GM, Khaira N. Studi Retrospektif Faktor Risiko Perokok Pada Penderita Hipertensi Di Wilayah kerja Puskemas Peukan Bada Kabupaten Aceh besar Tahun 2014. J Kesehat Ilm Nasuwakes. 2015;8(1):14-22.

17. Firmansyah MR. Hubungan Merokok dan Konsumsi Kopi dengan Tekanan Darah pada Pasien Hipertensi. J Kesehat. 2017;8(2):263268.

18. Oktavia F, Martini S. Besar Risiko Kejadian Hipertensi Berdasarkan Faktor Perilaku Pada Tentara Nasional Indonesia (Tni). Media Kesehat Masy Indones. 2016;12(3):127-136. doi:10.30597/MKMI.V12I3.1067

19. Saladini F, Benetti E, Fania C, Mos L, Casiglia E, Palatini P. Effects of smoking on central blood pressure and pressure amplification in hypertension of the young. Vasc Med (United Kingdom). 2016;21(5):422-428. doi:10.1177/1358863X16647509

20. Ain Q ul, Regmi K. The effects of smoking in developing hypertension in Pakistan: a systematic review. South East Asia J Public Heal. 2015;5(1):4-11. doi:http://dx.doi.org/10.3329/seajph.v5i1.24 845

21. Farabi AF, Revilla G. Artikel Penelitian Hubungan Kebiasaan Merokok dengan Tekanan Darah pada Siswa SMK N 1 Padang. J Kesehat Andalas. 2017;6(2):429434.

22. Leone A. Smoking and hypertension. MedCrave. 2015;2(2):1-7. doi:10.3109/10641969309037104

23. Lasianjayani T, Martini S. Hubungan antara obesitas dan perilaku merokok terhadap kejadian hipertensi. J Berk Epidemiol Nop 2014. 2014;2(3):286-296.

24. Anandkumar, Shilpa P, Bangera S, Souza UD. a Comparative Study of Cardiorespiratory Functions in Tobacco Smokers and Non Smokers Among Adult Males Study of Functions in. IJCRR Sect Healthc Sci J Impact Factor 4016. 2015;7(7):1-5.

25. Li G, Wang $\mathrm{H}$, Wang $\mathrm{K}$, et al. The association between smoking and blood pressure in men: A cross-sectional study. BMC Public Health. 2017;17(1):1-6. doi:10.1186/s12889-017-4802-x

26. Gao K, Shi X, Wang W. The life-course impact of smoking on hypertension, myocardial infarction and respiratory diseases. Sci Rep. 2017;7(1):1-7. doi:10.1038/s41598-017-04552-5

27. Kabo P. Penyakit Jantung Koroner, Penyakit Atau Proses Almiah? Jakarta: Badan Penerbit Fakultas Kedokteran Universitas Indonesia; 2014.

28. Ordóñez-Mena JM, Schöttker B, Mons U, et al. Quantification of the smoking-associated 
cancer risk with rate advancement periods: Meta-analysis of individual participant data from cohorts of the CHANCES consortium. BMC Med. 2016;14(1). doi:10.1186/s12916-016-0607-5

29. Tisa K AN. Hubungan Antara Kebiasaan Merokok Dengan Tekanan Darah Meningkat Karyawan Laki-Laki Di Nasmoco Semarang the Relation Between Smoking Habit With Increased Blood Pressure Male Employee in Nasmoco Semarang. J Kesehat Masy Univ Diponegoro. 2012;1(2):241-250. http:/ejournals1.undip.ac.id/index.php/jm 